\title{
САРЛАГИЙН ХӨӨВРИЙН ТЕХНИКИЙН ШИНЖ ЧАНАР
}

\author{
Ц.Хишигжаргал, Д.Энхтуяа, Б.Лувсаншарав, Д.Байгалмаа, Э.Оюунсүрэн
}

Хөдөө аж ахуйн их сургууль

\section{ХУРААНГУЙ}

Сарлагийн хөөврийн техникийн шинж чанар болон тэдгээрийн хоорондын хамаарльг энэхүY судалгаагаар тодорхойлов. Судалгааны үр дүнгээс үзэхэд 1 настай сарлагийн хөөврийн атирааны гүний дундаж утга нь 76,7 град/мм, хоёр настайд 67,9 град/мм, гурван настайд 56,9 град/мм, дөрвөн настай сарлагт 50,4 град/мм, таван настайд 47,8 град/мм тус тус байна. Сарлагийн хөөврийн голч нь 16,2 мкм-аас 29,66 мкм-ын хооронд хэлбэлзэж 1 настай сарлагийн хөөврийн голчийн дундаж утга нь 18,4 мкм, квадрат хазайлт нь $\pm 5,3$, жигд бусын итгэлиүүр нь 28,8 хувь байснаа цุаашдаа нас ахих тутам бүдүүрсээр 5 настайд хөөврийн голчийн дундаж утга нь 25,5 мкм, квадрат хазайлт нь $\pm 8,3$, жигд бусын илтгэлиүүр нь 32,5 хувьд хүрч байна. Сарлагийн хөөврийн урт нь 23,0 мм-ээс 41,9 мм-ийн хооронд хэлбэлзэж байна. Нэг настай сарлагийн хөөврийн ноолуур хамгийн урт 37,2 мм байхад, 2 настайд 35,2 мм, 3 настайд 32,6 мм, 4 настайд 29,3 мм, 5 настайд 27,5 мм тус тус болж еарлагшипнас дагаж буурч байна. Энэхүу хөөврийн техникийн шинж чанаруудын нас дагасан өөрчлөлт жигд, хэвийн тархалттай болохыг тогтоосон. Хөөврөн иирхэгтийн атираа, голчийн хоорондын шүтэлиээний илтгэлиүүр -0,79 буюу хүчтэй урвуу байна. Харин атираа, уртылн хоорондын шүтэлиээний илтгэлиүүр нь 0,86 буюу хүчтэй шууд байхад голч, уртын хоорондын шүтэлиээний илтгэлиүҮр -0,75 буюу хүчтэй урвуу хамааралтай байна.

TYЛХУУР УГ: атирааны гүн, ширхэгтийн голч, уртын статистик үзүүлэлт, шүтэлцээний математик загвар, илтгэлцүүрийн матриц

\section{ҮНДЭСЛЭЛ}

Эрдэмтдийн судалгаанаас үзэхэд сарлагийн нас ахих тутам их биеийн хөөврийн ноолуур, сор үс, завсрын үсний жингийн харьцаа өөрчлөгдөхийн хамт мөн үсний уртын хэмжээ өөрчлөгдөнө. Сарлагийн нялх тугалын үсний ширхэгтийн дундаж урт ноолуурынх $2.01 \mathrm{~cm}$, сор үснийх 3.72 см, завсрын үснийх 2.90 см байхад бярууных дээрх дарааллаар $6.67 \mathrm{cm;} 8.69$ см; 8.08 см тус тус байна. Харин бяруунаас дээш насанд төрөл бүрийн үсний хэмжээ богиносож 10-аaс дээш настай сарлаг үнээний ноолуур 4.1-3.7, сор үс
7.6-8.3, завсрын үс 6-5.4 см болж байна. (Т.БатЭрдэнэ1961,1986). 2,5,6,7

Завсрын болон сор үс бяруу, шүдлэн насандаа хамгийн урт ургаж цаашид аажим богиносоор 10-аaс дээш насанд бүх төрлийн үс шингэрдэг байна. Жао Лоончины /1994/ судалгаагаар сарлагийн үсний жинхэнэ урт нь биеийн хэсэг болон үсний төрлөөс хамааран эрс тэс ялгаатай байдгийг тогтоосон. Үүнтэй ижил төстэй үр дүнг Жанг Роончанг нарын /1989/ судалгаа харуулж байна. Сор үсний урт 8.9-21.1 см, завсрын үс нь 
5.3-13.0 см -ийн хооронд тус тус хэлбэлзэж дээрх хоёр үсний хамгийн урт нь биеийн бөөрний хэсэгт, хамгийн богино нь далны хэсэгт байна. ${ }^{5,8}$

Үсний голч нь үсний төрлөөс гадна ҮҮлдэр, нас хүйснээс хамаарна. (Т.Бат-Эрдэнэ 1961, 1986, Ванг, Юүяанг 1983, Жао Лоончин 1994) 3,8 Тугалаас бяруунд шилжих насанд сарлагийн үсэн бүрхэвч дэх ноолуур, сор үс, завсрын үснүүдийн урт, голч нь илт ялгаатай болж байна. Үүнд: бярууны ноолуур хамгийн нарийн (17.87 микрон), цааших насандаа аажим бүдүүрч байна. Cop үс, завсрын үс ч нэгэн адил нас ахих тутам энэ зүй тогтлоор өөрчлөгдөж байна. Т.БатЭрдэнэ/1961,1986/, Жао Лоончин /1994/ нарын

\section{СУДАЛГААНЫ МАТЕРИАЛ, АРГА ЗУЙ}

МААЭШХ-ийн “Ноолуурын дээж авах бэлтгэх шинжлэх нэгдсэн арга зүй” дагуу судалгаанд 5 аймгийн 14 сумын 70 суурийн 350 сарлагаас хөөврийн дээжийг авсан. Тухайн газар нутгийн онцлог, малын нас хүйснээс хамаарч сарлагийн биеийн зөөлөн үсний гуужих џағ хугацаа харилцан адилгүй байдаг учраaс 3-p сарын сүүлээс эхлээд 7-p сарын хооронд судалгааны дээжийг авсан болно. Сонгосон сум, орон нутаг тус бүрээс нийт сарлагийг төлөөлүүлэн 5 суурийн өөр хоорондоо төрлийн холбоогүй, 1-5 насны сарлаг судалгаанд хамруулав. Сарлагийн хүзүҮ хоолой, бөөр, хонгоны хэсэг тус бүрийн 5 судалгаагаар сарлагийн үсний голч нь биеийн хэсгүүдээс хамаарч ноцтой өөрчлөлтгүй байна гэсэн ижил дүгнэлтэнд хүрчээ. ${ }^{2,3,8}$

Монгол сарлагийг биологи, аж ахуйн ашигтай шинж тэмдгийн талаас нь эрдэмтэд нилээд олон судалгаа явуулсан боловч хөөврийн шинж чанарын Үзүүлэлтүүдийг үйлдвэрлэлийн технологитой уялдуулан хийсэн ажил хомс байна. Иймээс монгол сарлагийн үсний ширхэгтийн төрлийг нарийвчлан судалж үйлдвэрийн нөхцөлд боловсруулан бэлэн бүтээгдэхүүн үйлдвэрлэх технологийн болон бүтээгдэхүүний нэр төрлийн шийдлийг гаргах анхдагч материалыг зөв бүрдүүлэх нь энэхүҮ судалгааны ажлын үндэслэл болж байна.

$\mathrm{cm}^{2}$ талбайгаaс тусгай зориулалтын самаар самнаж дээж авав.

Сүүлийн үед OFDA-100 багаж дээр ширхэгтийн голчийг тодорхойлохын хамт ширхэгтийн 1 мм нумын уртад харгалзах өнцгөөр ширхэгтийн атирааг тодорхойлдог аргачлалыг сонгон Олон улсын Ноосон Нэхмэлийн байгууллагын баталсан IWTO 47-01 стандартын дагуу хэмжилт хийсэн болно. Нумын 2 төгсгөлийн цэгээс шүргэгч татсан перпендикуляр шулууны огтлолцолд ҮҮсэх өнцөг А-гаар ширхэгтийн атирааны өнцөг (град/ мм) -аар илэрхийлдэнэ.

\section{СУДАЛГААНЫ ҮР ДУН}

Сарлагийн хөөврийн техникийн шинж чанаруудаaс БНМС-ийн эрдмийн зөвлөлийн хурлаар баталсан судалгааны ажлын арга зүйн дагуу хөөврөн ширхэгтийн атираа, голч, урт зэрэг Үзүүлэлтүүдийг сонгон авч хэмжилт

хийсэн. Хэмжилтийн тоон утгуудыг Data analysis программын Descriptive Statistic Covariance ${ }^{1,4,5,9}$ дэд программаар боловсруулан дээрх шинж чанарын статистик үзүүлэлтүүдийг тодорхойлж 1-р хүснэгтээр харууллаа.

Хүснэгт 1

Сарлагийн хөөврөн ширхэгтийн атираа, голч, уртын статистик үзүүлэлт $(\mathrm{n}=100)$

\begin{tabular}{|c|c|c|c|c|c|c|c|}
\hline \multirow[b]{2}{*}{$\begin{array}{c}\text { Техникийн шинж } \\
\text { чанар }\end{array}$} & \multirow[b]{2}{*}{ 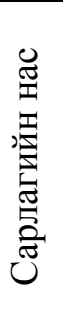 } & \multicolumn{6}{|c|}{ Статистик үзүүлэлт } \\
\hline & & 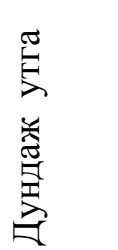 & 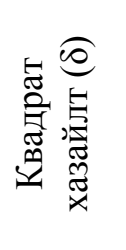 & 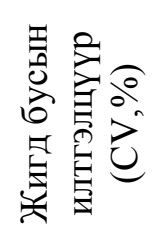 & 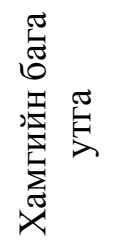 & 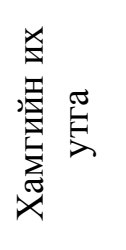 & 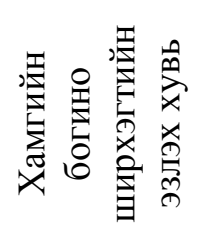 \\
\hline $\begin{array}{c}\text { Атирааны гүн } \\
\text { (град/ мм) }\end{array}$ & $\begin{array}{l}1 \\
2 \\
3\end{array}$ & $\begin{array}{c}76,7 \\
67,9 \\
56,9\end{array}$ & $\begin{array}{l} \pm 8,3 \\
\pm 8,2 \\
\pm 7,3\end{array}$ & $\begin{array}{l}10,8 \\
12,1 \\
12,8\end{array}$ & $\begin{array}{l}61,7 \\
52,9 \\
41,1\end{array}$ & $\begin{array}{l}98,7 \\
84,9 \\
73,1\end{array}$ & $\begin{array}{l}- \\
- \\
-\end{array}$ \\
\hline
\end{tabular}




\begin{tabular}{lccccccc} 
& 4 & 50,4 & $\pm 6,5$ & 12,9 & 37,3 & 65,3 & - \\
Голч & 5 & 47,8 & $\pm 6,6$ & 13,8 & 31,1 & 63,1 & - \\
(мкм) & 1 & 18,4 & $\pm 5,3$ & 28,8 & 16,2 & 22,2 & - \\
& 2 & 19,6 & $\pm 5,9$ & 30,1 & 16,36 & 22,36 & - \\
& 3 & 21,5 & $\pm 7,5$ & 34,1 & 17,8 & 25,3 & - \\
Урт (мм) & 4 & 24,5 & $\pm 8,0$ & 32,7 & 22,1 & 28,1 & - \\
& 5 & 25,5 & $\pm 8,3$ & 32,5 & 20,66 & 29,66 & - \\
& 1 & 37,2 & $\pm 12,7$ & 34,1 & 32,9 & 41,9 & 22,1 \\
& 2 & 35,2 & $\pm 12,7$ & 36 & 31,7 & 40,7 & 29,1 \\
& 3 & 32,6 & $\pm 14,0$ & 42,8 & 29,1 & 36,6 & 36,4 \\
& 4 & 29,3 & $\pm 13,2$ & 45,1 & 25,5 & 33 & 46,1 \\
& 5 & 27,5 & $\pm 12,7$ & 46,3 & 23 & 32 & 47,4 \\
\hline
\end{tabular}

1-p хүснэгтээс үзэхэд сарлагийн хөөврийн атирааны гүн нь 31,1 град/мм 98.7 град/мм-ын хооронд хэлбэлзэж байна. 1 настай сарлагийн хөөврийн атирааны гүний дундаж утга нь 76,7 град/мм, хоёр настайд 67,9 град/мм, гурван настайд 56,9 град/мм, дөрвөн настайд 50,4 град/мм, таван настайд 47,8 град/мм тус тус байна. Харин тэдгээрийн квадрат хазайлтууд нь нэг настай сарлагт $\pm 8,3$ град/мм, хоёр настайд $\pm 8,2$ град/мм, гурван настайд $\pm 7,3$ град/мм, дөрвөн настай сарлагийн хувьд $\pm 6,5$ град/мм, тав настайд $\pm 6,6$ град/мм байна.

Сарлагийн нас бүрийн хөөврийн атирааны гүний жигд бусын илтгэлцүүр нь нэг настай сарлагт 10,8 хувь, цаашид нас ахих тутам ихсэж 13.8 хувь болж байна. Бидний хийсэн дээрхи судалгаанаас үзвэл сарлагийн хөөврийн атирааны гүний дундаж утга нь 1 настайдаa хамгийн их байгаад цаашид нас ахих тутам буурч, харин атирааны гүний жигд бусын хувь нь бага насны сарлагийн хөөвөрт харьцангуй бага байгаа нь харагдаж байна.

Дээрх судалгаанаас харахад сарлагийн хөөврийн голч нь 16,2 мкм-аaс 29,66 мкм-ын хооронд хэлбэлзэж 1 настай сарлагийн хөөврийн голчийн дундаж утга нь 18,4 мкм, квадрат хазайлт нь $\pm 5,3$, жигд бусын итгэлцүүр нь 28,8 хувь байгаад цаашдаа нас ахих тутам бүдүүрсээр 5 настай сарлагийн хувьд хөөвөр голчийн дундаж утга нь 25,5 мкм, квадрат хазайлт нь $\pm 8,3$, жигд бусын илтгэлцүүр нь 32,5 хувьд хүрч байна.

\section{Хөөврөн ширхэгтийн техникийн шинж чанарын тархалт}

Сарлагийн хөөврийн атираа, голч, уртын тархалтын муруйг нас бүр дээр илэрхийлэхийн тулд Гистограммын аргыг ашиглав. Туршилтын тоон материалыг Data analysis программын Descriptive Statistic Histogram Frequence Polygan $^{10,11}$ зэрэг дэд программаap боловсруулав. ${ }^{1,4,9,12,13}$ Боловсхуулалтын дүнгээс үзэхэд сарлагийн хөөврийн атирааны гүн, голч,
Харин сарлагийн хөөврийн урт нь 23,0 мм-ээс 41,9 мм-ийн хооронд хэлбэлзэж байна. Нэг настай сарлагийн хөөврийн ноолуур хамгийн урт буюу 37,2 мм байхад 2 настайд 35,2 мм, 3 настайд 32,6 мм, 4 настайд 29,3 мм, 5 настайд 27,5 мм тус тус болж сарлагийн нас дагаж буурч байгааг харуулж байна.

Нэг настай сарлагийн хөөврийн атирааны гүнийг 100 хувь гэж үзвэл энэ үзүүлэлт хоёр настай болоход $11,4 \%$, гурван настай болоход $25,7 \%$, дөрвөн настай болоход $34,67 \%$, таван настай болоход $37,67 \%$ тус тус буурч байна. Харин хөөврийн голч нэг настай үеийнхийг 100 хувь гэвэл хоёр настай болоход $6,52 \%$, гурван настай болоход 16,8\%, дөрвөн настай болоход $33,15 \%$, таван настай болоход 38,58\%-иар тус тус нэмэгдэж байна. Энэ хоёр үзүүлэлтийн тоон утгыг харьцуулан үзвэл сөрөг хамааралтай болох нь харагдаж байна. Өөрөөр хэлбэл атирааны гүний 1 мм-т оногдох өнцөг буурах тутам голч нэмэгдэж байна. Харин нэг настай сарлагийн хөөврийн уртыг $100 \%$ гэж үзвэл 2 настай болоход урт нь 5,37\%, гурван настай болоход $12,36 \%$, дөрвөн настай болоход $21,2 \%$, таван настай болоход 26,07 хувиар богиносож байна. Энэхүу ширхэгтийн уртын үзүүлэлт сарлагийн настай шууд холбоотойгоор өөрчлөгдөж байна. Иймээс нас дагаад хөөврийн техникийн шинж чанаруудын өөрчлөлтийн тархалт жигд тархаж байна уу гэдийг тогтоох шаардлага дээрх судалгаанаас урган гарч байна.

уртын хэмжилтүүд дундаж утгаaсаa хоёр тийшээ жигд сарнин тархсан харагдаж байгаa боловч тэдгээрийн тархалтын хүрээ $\pm 3 \delta$ зайд тархаж байгааг эсэх нь тодорхой бус байна.

Иймээс судалгааны хэмжилтийн тоон утгууд дундаж утгаасаа хоёр тийш $\pm 3 \delta$ зайд яаж тархсанг Data Analysis программын Descriptive Statistic Z score (test) ${ }^{1,4}$ зэрэг дэд программыг ашиглан тодорхойлов. Хэмжилтийн үр дүнгийн боловсруулалтаас үзэхэд янз бүрийн насны 
сарлагийн хөөврийн атираа, голч, урт тус бүрийн хэмжилтийн тоон утгууд дунджаасаа $\pm 1 \delta$ зайд 68,3 хувь, $\pm 2 \delta$ зайд 95,44 хувь, $\pm 3 \delta$ зайд 99,72 хувь тус тус тархан хазайсан байв. Цаашид

\section{Сарлагийн хөөврийн техникийн шинж чанарын хоорондын хамаарал}

Сарлагийн хөөврийн атираа, голч, уртын тоон утгууд хэвийн тархалттай санамсаргүй хэмжигдэхүүн учраас тэдгээрийн хоорондын харилцан хамаарлыг шүтэлцээний математик загвар, хос шүтэлцээний итгэлцүүр тодорхойлох аргаap Data Analysis программын Descriptive эдгээр хөөврийн атираа, голч, урт гэсэн техникийн шинж чанарууд хоорондоо ямар хамааралтай болохыг тогтоох шаардлагатай болж байна.

Statistic Correlation дэд программыг ашиглан тогтоов. ${ }^{1,4}$ Боловсруулалтын үр дүнд хөөврийн техникийн шинж чанарын хоорондох харилцан хамааралын шүтэлцээний математик загвар, хос шүтэлцээний итгэлцүүр тус бүрийг тодорхойллоо. Хөөврийн техникийн шинж чанарын хоорондын харилцан хамаарлын математик загварыг гарган авсан. ( 2-р хүснэгт)

Хүснэгт 2

Сарлагийн хөөврийн техникийн шинж чанаруудын хоорондох харилцан хамаарлын шүтэлцээний математик загвар

\begin{tabular}{ccc}
\hline № & Техникийн шинж чанар & Шүтэлцээний математик илэрхийлэл \\
\hline 1 & Хөөврийн атираа ба голч & $\mathrm{Y}=-3,112 \mathrm{x}+127,76$ \\
2 & Хөөврийн атираа ба урт & $\mathrm{Y}=2,6602 \mathrm{x}-26,055$ \\
3 & Хөөврийн голч ба урт & $\mathrm{Y}=-1,086 \mathrm{x}+55,985$ \\
\hline
\end{tabular}

2-р хүснэгтэд үзүүлсэн шүтэлцээний математик илэрхийлэлээс харахад хөөврийн атирааны гүн ба голч; голч ба урт; урт ба атирааны хоорондох харилцан хамаарал нь нэг хүчин зүйлт шугаман хамааралтай болох нь тогтоогдлоо. Цааш нь тэдгээрийн хоорондох шугаман хамаарлын зэргийг үнэлэхдээ шүтэлцээний болон детерминацийн илтгэлцүүрийг ашиглав. ${ }^{1,4}$ Хөөврийн техникийн шинж чанарын хоорондох хос шүтэлцээний матрицыг 3 -р хүснэгтээр ҮзҮҮлэв.

Хүснэгт 3

Сарлагийн хөөврийн техникийн шинж чанарын хос шүтэлцээний илтгэлцүүрийн матриц

\begin{tabular}{lcccc}
\hline \multicolumn{1}{c}{ ҮзҮүлэлт } & $\begin{array}{c}\text { Голч } \\
\text { (мкм) }\end{array}$ & $\begin{array}{c}\text { Атираа, } \\
\text { (град/мм) }\end{array}$ & $\begin{array}{c}\text { Урт } \\
\text { (мм) }\end{array}$ & $\begin{array}{c}\text { Атирааны квадрат } \\
\text { хазайлт (град/мм) }\end{array}$ \\
\hline Голч (мкм) & 1 & $-0,79$ & $-0,75$ & $-0,48$ \\
Атираа (град/мм) & $-0,79$ & 1 & 0,86 & 0,51 \\
Урт ( мм) & $-0,75$ & 0,86 & 1 & 0,55 \\
Атирааны квадрат & & 0,51 & 0,55 & 1 \\
хазайлт (град/мм) & $-0,48$ & & \\
\hline
\end{tabular}

Энэ шүтэлцээний илтгэлцүүрийн тоон утгаар үнэлэх аргачлалын дагуу 3-р хүснэгтэд үзүүлсэн хөөврөн ширхэгтийн шинж чанарын хоорондын хамаарлыг авч үзэхэд хөөврөн ширхэгтийн атираа, голчийн хоорондын шүтэлцээний илтгэлцүүр $-0,79$ буюу хүчтэй урвуу байна.
Харин атираа, уртын хоорондын шүтэлцээний илтгэлцүүр нь 0,86 буюу хүчтэй шууд байхад голч, уртын хоорондын шүтэлцээний илтгэлцүүр $-0,75$ буюу хүчтэй урвуу хамааралтай байна.

\section{ДУГНЭЛТ}

1. Нэг настай сарлагийн хөөвөр нь атирааны гүн ихтэй, нарийн, урт, жигд бусын хувь бага байхад нас ахих тутам хөөврийн атираа багасан, ширхэгт бүдүүрч, богиносон улмаар богино ширхэгтийн эзлэх хувь нэмэгдэж

байна. Харин бусад малын үсний ширхэгтийн голч нарийсахад урт нь нэмэгддэг бол сарлагийнх эсрэг богино болоход насаа дагаад үсний ширхэгт бүдүүрч байна. 
2. Хөөврийн атираа, голч, уртын тархалтын муруйнууд нас бүр дээрээ хэвийн тархалтын хуульд захирагдаж байна.

3. Хөөврийн атирааны гүн ба голч; урт ба голчийн хоорондох харилцан хамаарал нь урвуу шугаман хамааралтай байхад хөөврийн атирааны гүн ба уртын хоорондох харилцан хамаарал нь шууд шугаман хамааралтай байна.

\section{АШИГЛАСАН ХЭВЛЭЛ}

1. Авдай.Ч, Энхтуяа.Д. 2010. “Судалгаa шинжилгээний ажил гүйцэтгэх аргазүй”. УБ

2. Бат-Эрдэнэ.Т. 2002. "Монгол Үүлдэрийн сарлаг”. УБ

3. Бат-Эрдэнэ.Т. "Үхэр сүрэг”. УБ

4. Энхтуяа.Д. "Вопросе теории и практики первичное об работки прядении козего пуха" Sch.D диссертаци

5. Fujiwara,H., 1987. Study of the improvement of wool fibric quality. J.text. Mach.Soc. Japan, $33,78-85$

6. Hopkins, H.W., 1985. Objective measurement of cashmere and mohair. Proc. Fifth conf. on Animal breeding and Genetics, UNSW, Sydhey. 381-386. See also Aust.Angora Mohair J., 3(2) 33-40 (1986)

7. Moylan F.H., and McGregor, B.A., 1991. The opportunity for growing high guality strong cashmere, cashgora and superfine mohair in Australia proc.Aust.Assoc. of Animal breeding \& Genetics, 9:418-421

8. Gerald W einer, Han jianling, Long Ruijun. 2003/6. "The yak" second edition revised and englared
4. Сарлагийн хөөврийн атирааны гүн нь бусад Үзүүлэлтүүддээ хүчтэй нөлөөлж чадахуйц хамгийн чухал үзүүлэлт болох нь батлагдав. Үүнийг үндэслэлээр сарлагийн хөөврийн чанарыг үнэлэх, технологийн шийдэл гаргахад атирааны гүнийг ашиглах боломжтой байна.

9. Hunter,L., A.Braun and E.Gee, 1983. Coefficient of variation of fibre diameter of commercial raw and scoured mohair and mohair tops. SAWTRI.Bull., 17 (4) 8-13

10. Alvigini,P, 1989. Event at Nagoya. Rivista delle Technologie Tessile, 2 (3) 64-72 (in Italy)

11. American society for testing and materials, 1985. Standartspecifications for fineness of wool top or mohair top and Assignment of grade. Annual book of ASTM standards, Vol.07.02, 734-736. Standarts ASTM D-399185 (greasy) and D3992-85 (top); also D2130-85 (alpaca).

12. Kusch,P. and Stephani,G. 1984, Quantitative determination of Animal hairs in mixtures with wool and synthetic fibres, Schrigt. Der deutsches wollforschungsinstitutet, No. 96, 161

13. Smuts.S, L.Hunter and E.Gee, 1985. Effect of medullation and $\mathrm{CV}$ of diameter on the Airflow measured diameter of mohair. Tech.Rep. 560. South African wool and textile research institute, $11 \mathrm{pp}$. 